\title{
A UNIQUE OCCURRENCE OF A PSAMMOSTEID HETEROSTRACAN ON THE PERI-GONDWANAN SHELF IN THE LOWER/MIDDLE DEVONIAN BOUNDARY MARINE DEPOSITS
}

\author{
VALÉRIA VAŠKANINOVÁ', PETR KRAFT² \\ ${ }^{1}$ National Museum, Department of Palaeontology, Václavské náměstí 68, 11579 Praha 1, the Czech Republic; e-mail:valeria_vaskaninova@nm.cz. \\ ${ }^{2}$ Institute of Geology and Palaeontology, Faculty of Science, Charles University, Albertov 6, 12843 Praha 2, the Czech Republic; e-mail: \\ kraft@natur.cuni.cz.
}

Vaškaninová, V., Kraft, P. (2016): A unique occurrence of a psammosteid heterostracan on the peri-Gondwanan shelf in the Lower/Middle Devonian boundary marine deposits. - Fossil Imprint, 72(3-4): 155-160, Praha. ISSN 2533-4050 (print), ISSN 2533-4069 (on-line).

\begin{abstract}
A rare psammosteid heterostracan (Agnatha) occurrence in the Devonian of the Prague Basin is indicative of a dry land influence in the regional palaeogeography. This argument is strongly supported by the appearance of vascular plants, but the studied vertebrates allow us to presume a local brackish water environment. These conditions are considered to be related to a supposed land in the vicinity of the preserved relic of Devonian rocks in the Teplá-Barrandian unit. Such unique conditions were not repeated in the area despite the increasing extent of continental environment related to the rising Variscan Orogeny.
\end{abstract}

Key words: Agnatha, Psammosteida, Devonian, Prague Basin, local palaeogeography

Received: October 10, 2016 | Accepted: November 22, 2016 | Issued: December 30, 2016

\section{Introduction}

The volcano-sedimentary deposits forming the infill of the Prague Basin are situated in the central part of the Czech Republic. Although preserved as a small denudation relic in the Teplá-Barrandian unit of the Bohemicum, they represent one of the most significant palaeontological areas in the European Variscides, with more than a century and a half of fossil collecting history. In spite of this extensive collecting activity, agnathan remains were not known from the intensively studied Silurian strata of the Prague Basin until recently, and even now only as microfossils (Vaškaninová (2014) described rare findings of indeterminable thelodont scales from the Ludfordian of the Požáry Quarry).

In the Devonian, the only agnathan remains known are two separate head carapace plates of psammosteid heterostracans. Both were found at the same locality (Prastav Quarry, see below) and are currently stored in the National Museum in Prague (for the specimen not described herein see Růžička 1929: fig. I.2). The larger and more easily determinable specimen (National Museum inventory number Lc 62) was originally described as Psammosteus (Ganosteus) perneri RŮŽIČKA, 1929. Tarlo (1965) assigned the specimen to the genus Schizosteus OBRUCHEv, 1940 and based the species diagnosis on a unique dermal ornamentation of regular, well-separated tubercles. No new material has been found or, at least, available for study and revision. However, the occurrence of psammosteids in the Prague Basin itself will be briefly discussed in this paper.

\section{Geological and palaeontological settings}

Both psammosteid carapace plates were discovered at a single locality - the Prastav Quarry near the village Holyně south-west of Prague (Text-fig. 1; also named Holině by Růžička (1929) or Holin, Hlubocepy near Prague by Tarlo (1965)). The quarry is now abandoned, but its walls are well-accessible and preserved, because it is a part of the NPP U Nového mlýna area protected by State Law. The section in the Prastav Quarry is the international parastratotype of the Lower/Middle Devonian boundary, comprising the upper part of the Emsian Třebotov Limestone and the basal portion of the Eifelian Choteč Limestone (Text-fig. 1).

The upper part of the Třebotov Limestone is developed as light grey micritic nodular limestones, containing a rich fauna with goniatites (e.g. genera Mimagoniatites, Agoniatites, Gyroceratites), trilobites (genera Phacops, Scabriscutellum a.o.), bivalves (genera Panenka, Kralovna, Pantata) and tentaculites (Nowakia richteri, $N$. holynensis) (Chlupáč et al. 1979).

The basal portion of the Choteč Limestone is lithologically quite different from the uppermost part of the Třebotov Limestone (Chlupáč et al. 1979, Koptíková 2011) in relative deep-water facies of the shelf (Chlupáč 1998) or 


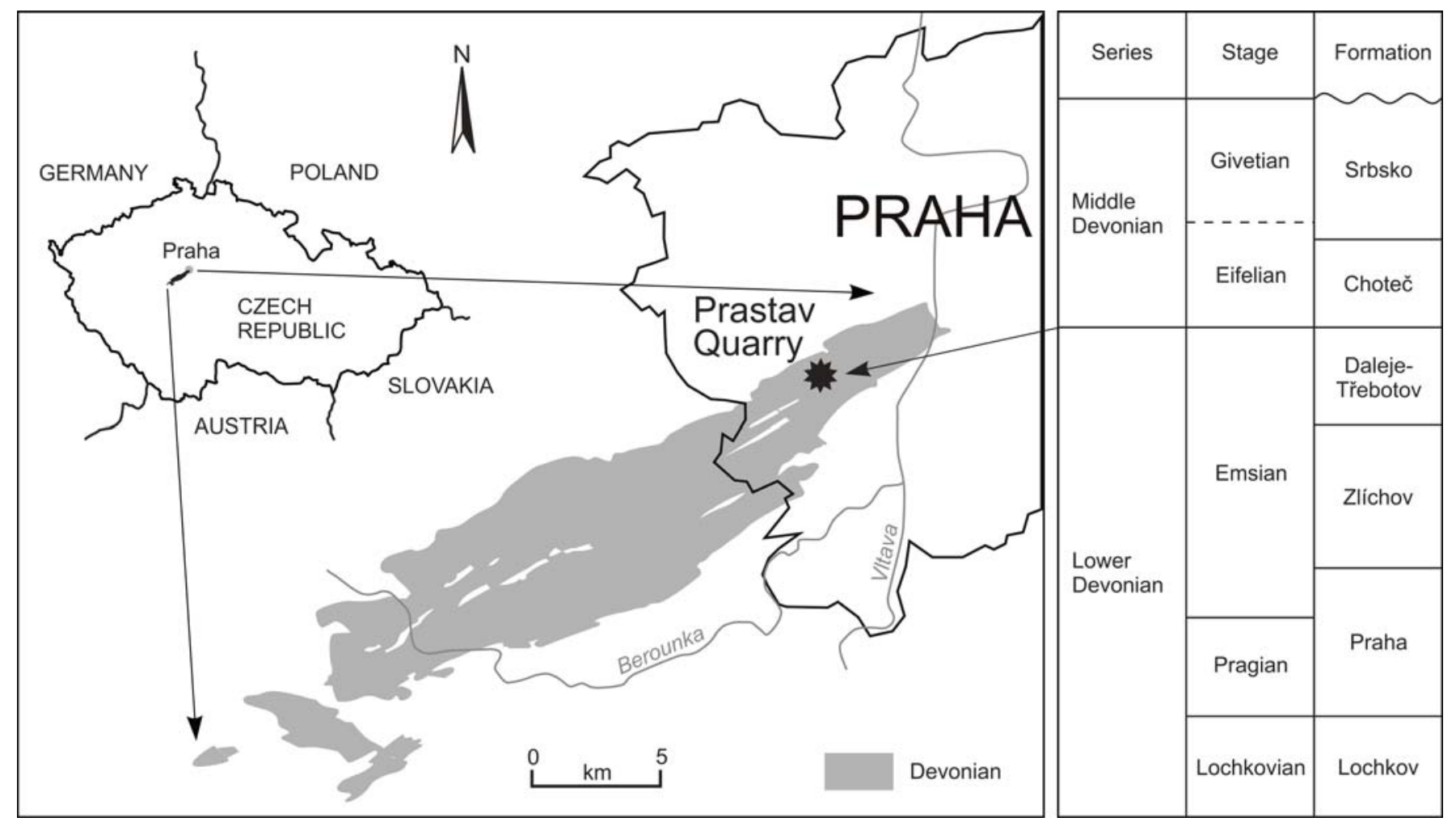

Text-fig. 1. Sketch map of Devonian in Prague Basin; position of Prastav Quarry marked with asterisk; stratigraphy of Devonian in Prague Basin (after Chlupáč 1998); Emsian/Eifelian boundary beds preserved in quarry related to locality with arrow.

slope (Koptíková 2011). It consists of grey to dark-grey micritic limestone, with thin intervals of dark calcareous shales. The fauna is characterized by the appearance of index goniatites Pinacites jugleri and Fidelites occultus, trilobites (e.g. genera Cyphaspides, Aulacopleura, Thysanopeltis) (Chlupáč et al. 1979), and brachiopods (e.g. linguliform genus Paterula, rhynchonelliform genera Chlupacina, Holynetes) (Havlíček and Racheboeuf 1979, Mergl 2001). Tentaculites (Nowakia sulcata) and other fauna also occur (Chlupáč et al. 1979). No other vertebrate remains are known from this locality.

\section{Systematic palaeontology}

\section{Schizosteus perneri (RŮŽIČKA, 1929)}

Pl. 1

For synonymy see Tarlo (1965: 63).

H o lo t y p e. NM-Lc 62 (National Museum, Prague).

Ty pe loc al ity. Prastav Quarry near Holyně, southwest of Prague.

Type horizon. Lower/Middle Devonian boundary beds, Emsian/Eifelian; Třebotov/Choteč limestones (see Discussion).

Description and remarks. Růžička (1929) acquired the specimen NM-Lc 62 from the quarry workers without being told about the exact circumstances of the discovery. He presumed the origin on the basis of contemporary labours in the central part of the quarry wall.
We refer to the previous determination of the specimen to Schizosteus perneri (RŮŽIČKA, 1929) as published by Tarlo (1965). We have no new data or observations to alter the diagnosis or the systematic position of the specimen, but we include remarks on some non-diagnostic features we have observed on the specimen.

The specimen represents a well preserved left branchial plate, with its dorsal surface exposed (P1. 1, Fig. 1). It is covered with superficial dermal ornament laterally, whereas in the mesial area, the ornament is exfoliated, and the inner vascular bone surface exposed (Pl. 1, Fig. 2c). The plate is ca. $17 \mathrm{~cm}$ long, slightly convex, except for the anterior-most margin, which is concave (Pl. 1, Fig. 2a). The overall convex shape is increasing towards the posterior end (Pl. 1, Fig. 2b). Posterior to the concave area, a transverse fracture is visible. The ornament is composed of well-bordered roundish tubercles with radially oriented ribs, slightly almond-shaped in cross section. Meeting points of the ribs are oriented towards the lateral margin of the plate (Pl. 1, Fig. 2d-e) on each well preserved tubercle. The tubercles are small at the anterior margin of the plate, and gradually enlarge towards the posterior end. In the anterior displaced area, a cross section of the dermal layers is visible (Pl. 1, Fig. 2f), as well as the shape of the tubercles, which are narrower at the base. The tubercles tend to be arranged in diagonal rows on most of the plate surface.

\section{Discussion}

As mentioned above, the exact stratigraphic layer which yielded the two specimens is unknown. However, Rưžička 
(1929) stated that the strata being quarried at the time of the discovery contained numerous goniatite fossils. He also wrote his assumption about the stratigraphic position on the original specimen label, where the type horizon is determined as the Choteč Limestone, horizon g $\gamma\left(\mathrm{G}-\mathrm{g}^{3}\right)$, of Eifelian age. This information was borrowed by Tarlo (1965). On the contrary, Chlupáč et al. (1979) considered the find to belong to the upper part of the Třebotov Limestone ( $N$. richteri or $N$. holynensis-Zone), based on the lithotype. Chlupáč's interpretation would place its origin in the uppermost Emsian strata. Lukševičs et al. (2010) agreed with Chlupáč, although they were citing Tarlo (1965).

This controversy has so far proven impossible to resolve conclusively, as there are no visible index fossils in the matrix surrounding the plate. We dissolved several small samples taken from the limestone slab with the specimen NM-Lc 62, but neither conodonts nor determinable tentaculites were found in the residuum. We identified only a number of very small, narrow cones as internal moulds of tentaculite shells, representing complete apical portions or their fragments. We subsequently tried to find tentaculites directly in the rock. We used the remaining small rock pieces from the slab with the fossil. After a short acid treatment, plenty of cross-cuts or internal and external moulds appeared on the corroded surface. As the external moulds seem to be smooth, without transversal rings, they can be assigned to the genus Styliolina, but the material does not allow species determination. Since this genus occurs in both the Třebotov and Choteč limestones, the value of the discovered tentaculites for precise stratigraphy is almost nil. The only argument we can present, however weak, supports Chlupáč's premise: Styliolina was more diversified and abundant in the Emsian than the Eifelian of the Prague Basin (Chlupáč et al. 1979). Since the sample was small, finding any such fossils at all in it indicates a relative abundance in the stratum.

Nevertheless, the lack of exact stratigraphic position of the specimens is not too serious. It is certain that both specimens were found in the Emsian/Eifelian boundary interval. In spite of lithological change, the limestones of this interval are of similar origin from turbidites or distal tempestites (Koptíková 2011).

Psammosteid heterostracans are known mainly from Laurussia (Lukševičs et al. 2010), and are quite rare in the Lower Devonian. The genus Drepanaspis SCHLÜTER, 1887 is one of the few genera known from the Pragian and Emsian. Drepanaspis occurs in south-western England and the Rhenish Slate Massif in western Germany (Tarlo 1965), both of which are considered Avalonian terranes, and in the middle-upper Emsian strata of the Ardenne Massif (Delsate et al. 2004), forming a part of Armorica.

The presence of a psammosteid heterostracan in the Prague Basin on the peri-Gondwanan shelf represents the easternmost occurrence of the group. It is also the earliest occurrence of the genus Schizosteus, which is otherwise known from the Eifelian and Givetian of Laurussia (Tarlo 1965, Lukševičs et al. 2010, Glinskiy 2014). Lukševičs et al. (2010) mentioned this occurrence, but associated it with the faunal interchanges with Armorica. However, Young (1990) supposes the faunal communication between Gondwana and Laurussia to commence in the Frasnian.
The Lower-Middle Devonian boundary deposits in the Prague Basin represent a purely marine succession of carbonates and calcareous shales, rich in fossils. Most of them are indicative of a marine environment, e.g. cephalopods (goniatites and "orthocones") are exclusively marine, and generally even stenohaline (Boyle and Rodhouse 2005).

Psammosteids are considered freshwater dwellers by Lebedev et al. (2010); coastal brackish-water or continental inhabitants by Lukševičs et al. (2010). The occurrence of two psammosteid dermal plates, one of them quite large, indicates the proximity of dry land. Its existence is also strongly supported by the occurrence of terrestrial plants, which first appeared in the Prague Basin during the Silurian (Obrhel 1962, 1968, Libertín et al. 2003). The occurrence of these plants in the Silurian and lowermost Devonian can be correlated with emerged volcanic islands (Měska and Kratochvíl 1946, Fiala 1970, Krríž 1992). In the Devonian, the existence of dry land was apparently caused mainly by tectonic activity (cf. Havlíček 1998).

Obrhel (1968) illustrated the diversity and frequency of occurrence of terrestrial plants in the marine sediments of the Prague Basin. He demonstrated a significant increase in both aspects toward the Srbsko Formation, the terminal unit of the basin, yielding abundant terrestrial plants, such as genera Protopteridium, Protolepidodendron, Pseudosporochnus (Obrhel 1961, 1968), often preserved in large fragments. This formation has a different character than other Devonian units. It is represented by a rhythmic siliciclastic succession, while other units are predominantly carbonate. This character of the Srbsko Formation is considered to be caused by the Variscan movements in the neighbouring areas (Chlupáč 1998). In fact, it reflects a supply of material transported from the near, continually approaching and uplifting Variscan Orogeny.

While the rich Givetian flora was related to large marginal areas of the emerged Variscan range, the upper Emsian and Eifelian terrestrial plants (Obrhel 1960, 1968, 1991) could originate from the limited continental conditions of islands. A lack of terrestrial plants in the Pragian and lower Emsian of the Prague Basin (Obrhel 1968, 1991) indicates an absence of dry land conditions near the area where the Devonian strata in the central Teplá-Barrandian Unit were deposited.

Psammosteids would be expected to follow the same trend as we can observe in terrestrial plants. They occur in sediments of the age when only the restricted habitats of scattered islands could exist. The subsequent expanding continental areas have not yielded any evidence of their presence. It is quite enigmatic with respect to a more complicated migration between islands, compared to the easily followable pathways along the Variscan coast in the period when the psammosteids flourished (Lebedev et al. 2010). It is a question which remains to be studied, because the limited occurrence of psammosteids in the Prague Basin indicates a complicated local palaeogeography. It also raises questions about the fresh and brackish water environments, their extent and the character of the dry lands and their coastal areas in the discussed period. Even if a carcass, postmortem transported from a far area, cannot be safely excluded, it can only raise questions about the distance, rather 
than existence of the suitable environment itself. As we are not able to estimate that distance, taking both aspects into account, we can estimate hundreds of meters to tens of kilometres. However, the occurrence of not a single but two independent remains of psammosteids and their absence in other parts of the Devonian section in the Prague Basin both indicate a temporary existing favourable habitat not far from the site of their discovery, rather than an accidental, unrepeated transport of two almost coeval carcasses from a long distance.

\section{Conclusions}

The occurrence of a psammosteid heterostracan in the Prague Basin during the Emsian/Eifelian turn supports the assumption about the existence of dry land nearby. In that time, probably a brackish coastal environment (Lukševičs et al. 2010) enabled the penetration of psammosteids to the area. The conditions suitable for this vertebrate group were apparently of very short duration, because psammosteids never reappeared in the Prague Basin.

\section{Acknowledgements}

The authors would like to acknowledge the vertebrate fossil curator B. Ekrt (National Museum, Prague) for his kind help with the specimen; V. Turek (National Museum, Prague) and P. Lukeš (Prague) for consultations on the lithology and stratigraphical position of the sample; A. Blieck (Université de Lille) and E. Randle (University of Manchester) for valuable comments on psammosteid heterostracans and for providing literature. Z. Johanson (Natural History Museum, London) is thanked for discussing the possible bone damage repair. We are grateful to L. Váchová for photographing the specimen, to L. Laibl for his help with computer graphics and to P. Daneš (all National Museum, Prague) for English corrections.

This study was supported by the Charles University Grant Agency project no. 1154214, the Charles University Research Development Schemes PRVOUK P44 (to P. K.) and by Ministry of Culture of the Czech Republic (DKRVO 2016/07, National Museum, 00023272).

\section{References}

Boyle, P., Rodhouse, P. (2005): Cephalopods. Ecology and Fisheries. - Blackwell Science Ltd., Blackwell Publishing, Oxford, Ames, 464 pp.

Chlupáč, I. (1998): Devonian. - In: Chlupáč, I., Havlíček, V., Křŕž, J., Kukal, Z., Štorch, P. (eds), Palaeozoic of the Barrandian (Cambrian to Devonian). Czech Geological Survey, Prague, pp. 101-133.

Chlupáč, I., Lukeš, P., Zikmundová, J. (1979): The Lower/ Middle Devonian boundary beds in the Barrandian area, Czechoslovakia. - Geologica et Palaeontologica, 13: 125-156.

Delsate, D., Blieck, A., Steemans, P. (2004): A psammosteid heterostracan (Vertebrata: Pteraspidomorphi) from the Emsian (Lower Devonian) of the Grand Duchy of Luxembourg. - Geologica Belgica, 7: 21-26.
Fiala, F. (1970): Silurské a devonské diabasy Barrandienu [Silurian and Devonian diabases of the Barrandian Basin]. - Sborník geologických věd, řada Geologie, 17: 7-89. (in Czech with English summary)

Glinskiy, V. N. (2014): New Records of Psammosteids (Heterostraci) from the Aruküla Regional Stage (Middle Devonian) of the Leningrad Region, Russia. Paleontological Journal, 48: 980-991. https://doi.org/10.1134/S0031030114090032

Havlíček, V. (1998): Prague Basin. - In: Chlupáč, I., Havlíček, V., Kříž, J., Kukal, Z., Štorch, P. (eds), Palaeozoic of the Barrandian (Cambrian to Devonian). Czech Geological Survey, Prague, pp. 39-41.

Havlíček, V., Racheboeuf, P. R. (1979): Chonetacea (Brachiopodes) du Silurien et du Dévonien de Bohême (Tchécoslovaquie). - Annales de Paléontologie (Invertébrés), 65(2): 69-138.

Koptíková, L. (2011): Precise position of the Basal Choteč event and evolution of sedimentary environments near the Lower-Middle Devonian boundary: The magnetic susceptibility, gamma-ray spectrometric, lithological, and geochemical record of the Prague Synform (Czech Republic). - Palaeogeography, Palaeoclimatology, Palaeoecology, 304: 96-112. https://doi.org/10.1016/j.palaeo.2010.10.011

Kř́̌ž, J. (1992): Silurian Field Excursions. Prague Basin (Barrandian), Bohemia. - Geological Series, National Museum of Wales, 13: 1-111.

Lebedev, O. A., Lukševičs, E., Zakharenko, G. V. (2010): Palaeozoogeographical connections of the Devonian vertebrate communities of the Baltica Province. Part II. Late Devonian. - Palaeoworld, 19: 108-128. https://doi.org/10.1016/j.palwor.2009.12.003

Libertín, M, Labut'a, R., Dašková, J. (2003): The oldest vascular plants from the Bohemian Massif. - Zprávy o geologických výzkumech v roce 2002: 127. (In Czech with English abstract)

Lukševičs, E., Lebedev, O. A., Zakharenko, G. V. (2010): Palaeozoogeographical connections of the Devonian vertebrate communities of the Baltica Province. Part I. Eifelian-Givetian. - Palaeoworld, 19: 94-107. https://doi.org/10.1016/j.palwor.2010.02.001

Mergl, M. (2001): Lingulate brachiopods of the Silurian and Devonian of the Barrandian (Bohemia, Czech Republic). - Acta Musei Nationalis Pragae, Series B - Historia Naturalis, 57(1-2): 1-49.

Měska, G., Kratochvíl, J. (1946): Hornina od Sv. Jana pod Skalou, uváděná pod názvem čedič [Geological and Petrographical Notes Concerning a Rock from the Neighbourhood of Sv. Jan pod Skalou, Classified as Basalt]. - Sborník Státního geologického ústavu ČSR, 13: 189-205. (in Czech with English and Russian summary)

Obrhel, J. (1960): Die Flora der Choteč-Kalke und Třebotov-Kalke (Eifel) des mittelböhmischen Devons. - Sborník Ústředního ústavu geologického, oddíl paleontologický, 25(1958): 99-107.

Obrhel, J. (1961): Die Flora der Srbsko-Schichten (Givet) des mitellböhmisches Devons. - Sborník Ústředního ústavu geologického, oddíl paleontologický, 26: 7-46.

Obrhel, J. (1962): Die Flora der Přidolischichten (Budňany-Stufe) des mittelböhmisches Silurs. - Geologie, 11: 83-97. 
Obrhel, J. (1968): Der Silur- und Devonflora des Barrandiums. - Paläontologische Abhandlungen, Abteilung B, Paläobotanik, 2: 661-706.

Obrhel, J. (1991): Rostlinné fosílie z nemetamorfovaného staršího paleozoika Čech a Moravy [Plant fossils from the non-metamorphic Early Palaeozoic of Bohemia and Moravia]. - Časopis pro mineralogii a geologii, 36(4): 263-277. (in Czech)

Obruchev, D. V. (1940): On some Psammosteids from the Middle Devonian of the Leningrad and Baltic Regions. Doklady Akademii Nauk SSSR, 28(8): 766-768.

Růžička, R. (1929): Psammosteus (Ganosteus) Perneri n. sp. Contribution à la connaissance des poissons du Paléozoïque de la Bohême. - Věstník Státního geologického ústavu Československé republiky, 5: 166-172.

Schlüter, C. (1887): Über Panzerfische aus dem rheinischwestfälischen Devon. - Sitzungsberichte der Niederrheinischen Gesellschaft für Natur- und Heilkundein Bonn, A, 1887: 120-128.

Tarlo, B. H. (1965): Psammosteiformes (Agnatha) - a review with descriptions of new material from the Lower Devonian of Poland. II. Systematic part. - Palaeontologia Polonica, 15: 1-168.

Vaškaninová, V. (2014): Preliminary report on the occurrence of vertebrate remains in the Silurian of the Prague Basin. - In: Zhan, R., Huang, B. (eds), Extended Summary, IGCP 591 Field Workshop 2014, Kunming, China, 12-21 August 2014. Nanjing University Press, Nanjing, pp. 170-172.

Young, G. C. (1990): Devonian vertebrate distribution patterns and cladistics analysis of palaeogeographic hypotheses. - In: McKerrow, W. S., Scotesse, C. R. (eds), Palaeozoic Palaeogeography and Biogeography. Geological Society Memoir, 12: 243-255.

https://doi.org/10.1144/GSL.MEM.1990.012.01.23

\section{Explanations of the plate}

\section{PLATE 1}

Schizosteus perneri (RŮŽıČKA, 1929), Prastav Quarry near Holyně, No. NM-Lc 62

1a. Left branchial plate in dorsal view.

1b. Schematic drawing of the plate, grey colour indicating areas with preserved dermal ornament.

2a. Anterior view.

2b. Posterior view.

2c. Detail of vascular bone layer.

$2 \mathrm{~d}-\mathrm{e}$. Details of dermal ornament in posterior area of plate. $2 \mathrm{f}$. Detail of dermal ornament in anterior area of plate.

Scale bars $=1 \mathrm{~cm}$; in $2 \mathrm{c}-\mathrm{f}$ scale bars $=1 \mathrm{~mm}$. 
PLATE 1
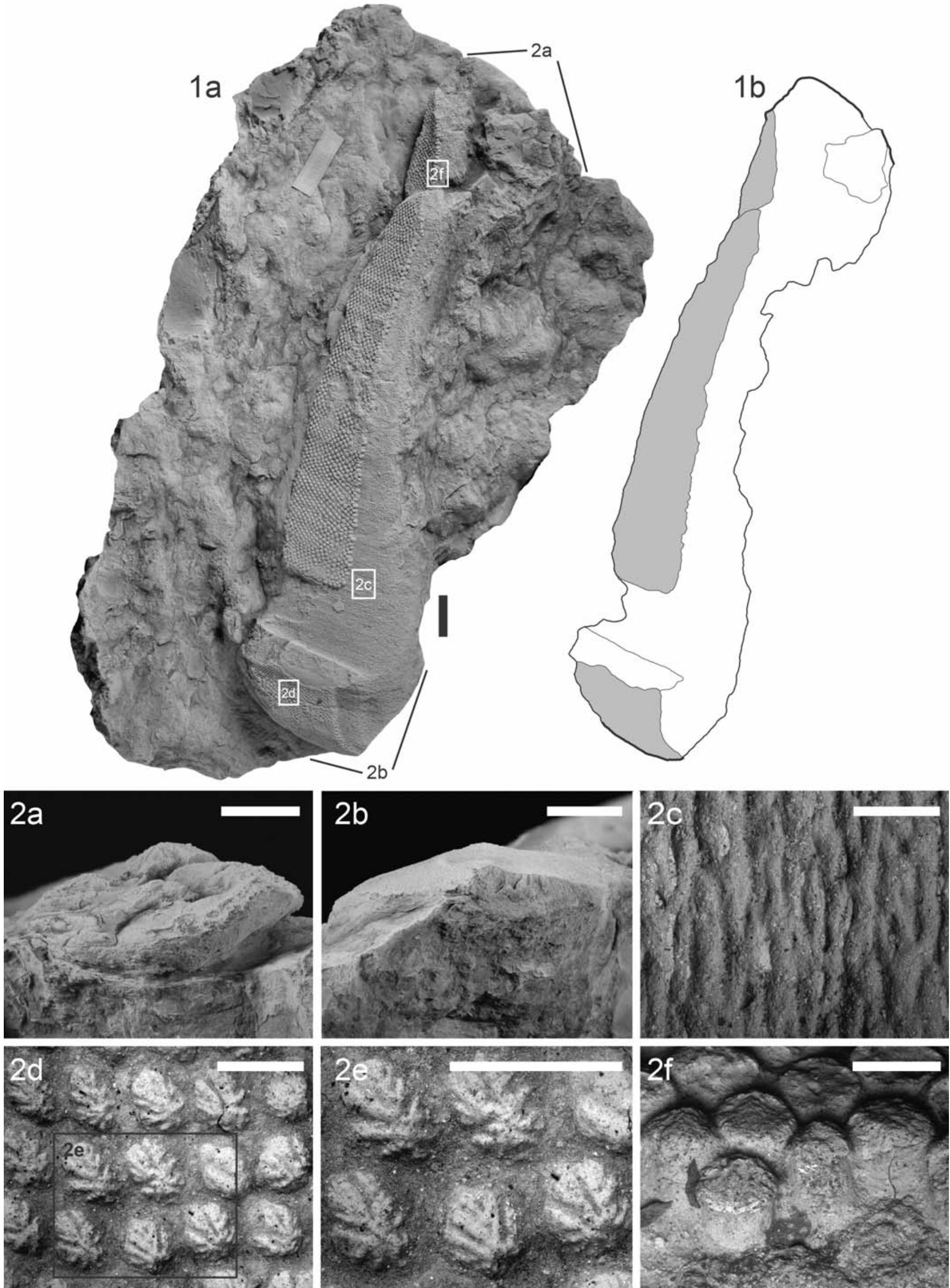